\title{
Adjunctive micronutrient supplementation for pulmonary tuberculosis
}

\author{
Rodrigo X Armijos, MD, ScD, (1) M Margaret Weigel, PhD, (') Rocío Chacon, MD, (1) \\ Luis Flores, RN, DPH, ${ }^{(1,2)}$ Armando Campos, MD. (2)
}

\author{
Armijos RX, Weigel MM, Chacon R, Flores L, Campos A. \\ Adjunctive micronutrient supplementation \\ for pulmonary tuberculosis. \\ Salud Publica Mex 2010;52:185-189.
}

\begin{abstract}
Objective. To assess the effect of micronutrient supplementation on tuberculosis (TB) patient outcomes. Material and Methods. The randomized, double-blinded, placebocontrolled study was conducted in pulmonary TB patients undergoing directly observed treatment short course/ tratamiento acortado estrictamente supervisado (TAES/ DOTS) at IMSS in Ciudad Juarez, Chihuahua, Mexico, who were recruited during August 2005-July 2006. Consecutive patients received zinc and vitamin $A$ supplements or matched placebo for four months. Dietary intake, blood zinc and vitamin A, immune response (IFN- $\gamma$,TNF- $\alpha$, and IL-I 0 mRNA), and sputum smear conversion were measured. Results. The proportion of micronutrient compared to placebo group subjects with a negative sputum smear by month 3 was significantly increased $(p=0.03)$. This occurred subsequent to increased TNF- $\alpha$ and IFN- $\gamma$ and decreased IL-I0 observed at month 2 . Micronutrient supplementation appeared to accelerate the beneficial therapeutic effect of chemotherapy. Conclusions. The earlier elimination of bacilli from sputum was associated with improved zinc status and ThI immune response. The therapeutic effect of vitamin A was less evident.
\end{abstract}

Key words: pulmonary; tuberculosis; zinc; vitamin A; cytokines; Mexico
Armijos RX, Weigel MM, Chacon R, Flores L, Campos A. Suplementación con micronutrientes como tratamiento adjunto para tuberculosis pulmonar.

Salud Publica Mex 2010;52:185-189.

\section{Resumen}

Objetivo. Determinar el efecto de la suplementación con zinc y vitamina $A$ o placebo en pacientes tratados por tuberculosis (TB). Material y métodos. Se realizó un ensayo aleatorizado en pacientes tuberculosos que iniciaron el tratamiento acortado estrictamente supervisado/ directly observed treatment short course (TAES/DOTS) en las clínicas del IMSS, Ciudad Juárez, Chihuahua, México, reclutados durante agosto 2005 -julio 2006. A cada paciente en forma aleatoria se le designó un código para recibir ya sea micronutrientes o placebo por cuatro meses, bajo el diseño doble ciego. Se evaluó la ingesta dietética, niveles de zinc y vitamina $A$ en sangre, respuesta inmune (IFN- $\gamma$, TNF- $\alpha$, IL- I0 mRNA en sangre) y bacilo ácido alcohol resistente (BAAR) en esputo. Resultados.Al tercer mes de la suplementación, la proporción de sujetos con BAAR negativo en el grupo de micronutrientes aumentó significativamente en relación con el grupo placebo $(p=0.03)$, que va asociado al previo (segundo mes) incremento de los niveles de TNF- $\alpha$, e IFN- $\gamma$ y disminución de los niveles de IL-I0. Conclusiones. Suplementación con los micronutrientes aparentemente aceleran el efecto terapéutico de la quimioterapia. La negativización temprana del BAAR en esputo se asoció con la recuperación del estatus de zinc y la respuesta Thl. El efecto terapéutico de vitamina $\mathrm{A}$ es menos evidente.

Palabras claves: tuberculosis; pulmonar; zinc; vitamina $A$; citokinas; México

(I) College of Health Sciences, University of Texas at El Paso, USA.

(2) Instituto Mexicano del Seguro Social. Cd. Juárez, Mexico.

Received on: May 7, 2009 • Accepted on: February 16,2010

Address reprint requests to: Dr. RX Armijos. Human Immunology and Nutrition Research Laboratory, Department of Health Promotion/MPH Program, College of Health Sciences, University of Texas at El Paso. Stanton Professional Building Suite 700,

I 100 North Stanton Street. 79902-058I El Paso,Texas, USA.

E-mail:rxarmijos@utep.edu 
$\mathrm{V}$ itamin A and zinc deficiencies are common features of pulmonary tuberculosis (TB).$^{1-3}$ Deficiencies of both micronutrients can reduce host defenses and immune response. ${ }^{3,4}$ This can potentially affect host response to anti-TB chemotherapy and patient outcome. Regulatory T cells (Treg) and Th2 type immune response appear to predominate in the early clinical evolution of TB and becomes more pronounced as the disease worsens. ${ }^{5-7}$ However, successful chemotherapy causes a return back towards a Th1 state. Thus, improving the micronutrient status of treated pulmonary TB patients may accelerate bacterial clearance and clinical healing ostensibly through improvement of immune response. $^{8}$

The evidence from prior studies is inconsistent regarding the potential therapeutic effects of vitamin $A$ or zinc supplementation given alone or combined with other micronutrients. ${ }^{9-11}$ In addition, the putative effects of adjunctive vitamin A and zinc supplementation on the immune response TB patients has not been investigated. The randomized, placebo-controlled, double-blind pilot study was conducted to assess the effectiveness of adjunctive vitamin $\mathrm{A}$ and zinc supplementation on the nutritional status, immune response, and sputum smear conversion of patients being treated for pulmonary TB. It was hypothesized that supplementation would accelerate sputum smear conversion by improving Th1 immune response leading to macrophage activation and Mycobacteria killing.

\section{Material and Methods}

Newly diagnosed pulmonary TB patients attending the Instituto Mexicano del Seguro Social (IMSS) outpatient services in Ciudad Juárez, Chihuahua State, Mexico, were recruited between August 2005-July 2006. Consecutive patients with a positive sputum smear, without prior history of TB or treatment, and who were aged 18-65 years were eligible for participation unless they were pregnant, breastfeeding, used corticosteroids, or had HIV, diabetes, or another serious co-morbidity. All subjects gave their written informed consent. The protocol was approved by the IMSS, Universidad Autonoma de Ciudad Juárez, and University of Texas at El Paso institutional review boards.

Subjects were randomized to the micronutrient or placebo groups. Micronutrient group subjects received four months of supplementation with $5000 \mathrm{IU} /$ day of vitamin A as retinyl acetate and $50 \mathrm{mg} /$ day elemental zinc as zinc chelate; placebo group subjects received organoleptically identical, matched placebos. A coinvestigator not involved in data collection or analysis maintained the study codes and allocated the supple- ments. Subject codes remained sealed until after completion of data analysis. All subjects received short-course, directly observed antibiotic therapy per IMSS guidelines: intensive 60-day treatment with isoniazid (300 mg/ day), rifampicin (600 mg/day), pyrazinamide $(1,600$ $\mathrm{mg} /$ day) and ethambutol (1200 mg/ day) followed by a sustained 45-dose therapeutic phase with isonizid (800 $\mathrm{mg} /$ dose) and rifampicin (600 mg/dose). Compliance with antibiotic and nutritional therapy was assessed on site at IMSS and during unscheduled home visits.

Face-to-face interviews and medical records were used to collect data on subject sociodemographic and clinical characteristics. Repeated 24-hour recalls, conducted at baseline and study months 1-4 and 6, estimated subject intakes of energy, zinc, vitamin A and other nutrients from food, supplements and other sources. The data were analyzed with the Food Processor diet analysis software. Subject BMI was calculated from observed weight and height data at baseline and months $1-4$ and 6 .

Ten $\mathrm{mL}$ blood samples were collected between 8-10:00 am for the nutritional and immunological analyses at baseline and months 2 and 6. Plasma zinc (inductively coupled plasma/optical emission spectroscopy) and serum retinol (HPLC) were analyzed. IFN- $\gamma$, TNF- $\alpha$, and IL-10 mRNA cytokine analyses were performed at the UTEP Human Immunology and Nutrition Research Laboratory using quantitative RT-PCR (Applied Biosystems). Direct microscopy conducted at the IMSS clinical laboratory detected Mycobacteria present in sputum smears collected at baseline and months 1-6. Sputum cultures were analyzed for Mycobacteria complex/species (PCR) and antibiotic sensitivity (Middlebrook 7H11 + OADC) at the El Paso City-County Health Department Tillman Laboratory.

Subject baseline data were analyzed to verify random assignment of subjects. The intent-to-treat principal was used to examine treatment effect. Mantel-Haenzel $\mathrm{X}^{2}$ or Fisher's exact test analyzed differences between proportions and Students' independent and paired t-test for mean between- and within-group differences. The multivariate analyses employed ANCOVA.

\section{Results}

Thirty-nine subjects with confirmed pulmonary TB and antibiotic drug sensitivity were randomized to the micronutrient $(n=20)$ or placebo groups $(n=19)$. Of these, two subjects in the micronutrient group were lost to follow-up due to moving out of the city and one for non-compliance. One placebo group subject died and two others were lost either due to non-compliance or pregnancy. As Tables I-II indicate, 
no statistically significant between-group differences were identified in the baseline characteristics of the remaining subjects in the micronutrient $(n=17)$ and placebo $(\mathrm{n}=16)$ groups.

Table II reveals that the mean dietary zinc intakes of the micronutrient but not placebo group showed

\section{Table I}

COMPARISON OF MICRONUTRIENT ( $\mathrm{N}=\mathrm{I7}$ ) AND PLACEBO $(\mathrm{N}=16)$ GROUP CHARACTERISTICS at baseline (Month 0)** Ciudad Juárez, Chihuahua, MeXico, 2005-2006

\begin{tabular}{|c|c|c|}
\hline & $\begin{array}{l}\text { Micronutrient } \\
\text { Group }(n=17)\end{array}$ & $\begin{array}{c}\text { Placebo } \\
\text { Group }(n=16)\end{array}$ \\
\hline & $\begin{array}{c}\text { Mean } \pm \text { S.D. } \\
\text { or } \\
\text { No. }(\%)\end{array}$ & $\begin{array}{c}\text { Mean } \pm \text { or.D. } \\
\text { or } \\
\text { No. }(\%)\end{array}$ \\
\hline \multicolumn{3}{|l|}{ Subject characteristics } \\
\hline Age (years) & $38.4 \pm 12.9$ & $37.7 \pm 17.2$ \\
\hline Sex (\% female) & $8(47.1)$ & $9(56.3)$ \\
\hline Education (years completed) & $7.8 \pm 2.2$ & $7.1 \pm 4.2$ \\
\hline Currently employed (full- or part-time) & $13(76.5)$ & $10(62.5)$ \\
\hline \multicolumn{3}{|l|}{ Occupation: } \\
\hline Factory worker & $7(4 I .2)$ & $7(43.8)$ \\
\hline Other blue collar trades & $6(35.3)$ & $2(12.5)$ \\
\hline Housewife & $2(11.8)$ & $3(18.8)$ \\
\hline White collar workers & $0(0.0)$ & $2(12.5)$ \\
\hline Unemployed/retired & $3(16.7)$ & $2(12.5)$ \\
\hline Current cigarette smoker & $2(11.8)$ & $\mathrm{I}(6.3)$ \\
\hline Body Mass Index $\left(\mathrm{kg} / \mathrm{m}^{2}\right)$ & $20.4 \pm 5.0$ & $22.6 \pm 4.2$ \\
\hline Underweight $(<18.5)$ & $8(47.1)$ & $3(18.8)$ \\
\hline Normal weight (I8.5-24.9) & $6(35.5)$ & $8(50.0)$ \\
\hline Overweight or obese $(\geq 25.0)$ & $3(17.7)$ & $5(3 I . I)$ \\
\hline \multicolumn{3}{|l|}{ Clinical and laboratory indicators } \\
\hline Positive sputum smear & $17(100.0)$ & $16(100.0)$ \\
\hline Positive sputum culture & $17(100.0)$ & $16(100.0)$ \\
\hline White blood cell count $\left(\times 10^{9}\right.$ cells/L) & $8.6 \pm 2.4$ & $7.1 \pm 2.3$ \\
\hline Hematocrit (\%) & $38.5 \pm 5.1$ & $40.7 \pm 4.3$ \\
\hline BCG scar present (\% yes) & $14(82.4)$ & $12(80.0)$ \\
\hline Pulmonary infiltration (any) & $20(100.0)$ & $19(100.0)$ \\
\hline Pulmonary cavities (any) & $12(85.7)$ & II (84.6) \\
\hline \multicolumn{3}{|l|}{ Self-reported signs and symptoms } \\
\hline Fatigue & $17(100.0)$ & $15(93.8)$ \\
\hline Fever & $15(88.2)$ & $13(81.3)$ \\
\hline Weight loss & $15(88.2)$ & $13(81.3)$ \\
\hline Persistent cough & $16(94.1)$ & $15(93.8)$ \\
\hline Chest pain & $10(58.8)$ & $7(43.8)$ \\
\hline Bloody sputum & $7(4 \mid .2)$ & $8(50.0)$ \\
\hline
\end{tabular}

Table II

COMPARISON OF UTRITIONAL STATUS INDICATORS IN THE MICRONUTRIENT $(\mathrm{N}=\mid 7)$ AND PLACEBO $(\mathrm{N}=16)$ groups at baseline (Month 0), SUPPLementation PERIOD (MONTHS I-4) AND POST-SUPplementation period (Month 6).* Ciudad Juárez, Chihuahua, MeXICO, 2005-2006

\begin{tabular}{|c|c|c|}
\hline & $\begin{array}{l}\text { Micronutrient } \\
\text { Group }(n=17)\end{array}$ & $\begin{array}{c}\text { Placebo } \\
\text { Group }(n=16)^{*}\end{array}$ \\
\hline & Mean \pm S.D. & Mean \pm S.D. \\
\hline \multicolumn{3}{|c|}{ Dietary intake indicators } \\
\hline \multicolumn{3}{|l|}{ Zinc (mg) } \\
\hline Month 0 & $6.18 \pm 4.7$ & $8.46 \pm 4.37$ \\
\hline Month I & $59.14 \pm 6.3^{1}$ & $11.6 \pm 13^{3}$ \\
\hline Month 2 & $59.67 \pm 4.9^{1}$ & $12.98 \pm 13.3^{3}$ \\
\hline Month 3 & $58.84 \pm 6.56$ & $11.52 \pm 17.1^{3}$ \\
\hline Month 4 & $57.80 \pm 4.76^{1}$ & $15.42 \pm 16.5^{3}$ \\
\hline Month 6 & $11.57 \pm 8.44$ & $9.26 \pm 7.22$ \\
\hline \multicolumn{3}{|c|}{ Vitamin A (IU) } \\
\hline Month 0 & $5329 \pm 4614$ & $3932 \pm 2591$ \\
\hline Month I & $9879 \pm 424 I^{\prime}$ & $20091 \pm 55692$ \\
\hline Month 2 & $9977 \pm 2628$ & $4561 \pm 4632^{3}$ \\
\hline Month 3 & $10873 \pm 5180^{2}$ & $4564 \pm 3434^{3}$ \\
\hline Month 4 & $10450 \pm 6627^{2}$ & $27886 \pm 5192$ \\
\hline Month 6 & $4905 \pm 3547$ & $4352 \pm 3458$ \\
\hline \multicolumn{3}{|l|}{ Energy (Kcal) } \\
\hline Month 0 & $2135 \pm 866$ & $2322+1021$ \\
\hline Month I & $2482 \pm 1077$ & $2438 \pm 1239$ \\
\hline Month 2 & $2670+995$ & $2528+1219$ \\
\hline Month 3 & $2546+1156$ & $2596+1244$ \\
\hline Month 4 & $2403 \pm 951$ & $3225 \pm 1723$ \\
\hline Month 6 & $2434 \pm|33|$ & $2571 \pm 980$ \\
\hline \multicolumn{3}{|l|}{ Protein (g) } \\
\hline Month 0 & $75.7 \pm 34.1$ & $86.2 \pm 40.0$ \\
\hline Month I & $98.7 \pm 41.7$ & $106.8 \pm 52.9$ \\
\hline Month 2 & $108.2 \pm 52.9$ & $108.9 \pm 46.2$ \\
\hline Month 3 & $96.7 \pm 29.4$ & $109.8 \pm 53.8$ \\
\hline Month 4 & $88.1+40.2$ & $119.4+59.5$ \\
\hline Month 6 & $95.5 \pm 64.3$ & $99.7 \pm 51.1$ \\
\hline
\end{tabular}

Biochemical indicators

Plasma zinc $(\mu \mathrm{g} / \mathrm{L})$

\begin{tabular}{lll} 
Month 0 & $738 \pm 168$ & $764 \pm 137$ \\
\hline Month 2 & $840 \pm 222^{2}$ & $662 \pm 105^{1,4}$ \\
\hline $\begin{array}{l}\text { Month 6 } \\
\text { Serum retinol }(\mu \mathrm{g} / \mathrm{dL}) \\
\text { Month 0 }\end{array}$ & $680 \pm 100$ & $739 \pm 138$ \\
\hline Month 2 & $29.4 \pm 13.3$ & $29.8 \pm 13.8$ \\
\hline $\begin{array}{l}\text { Month 6 } \\
\text { Serum albumin } \\
\text { Month 0 }\end{array}$ & $40.1 \pm 13.5$ & $36.9 \pm 10.0$ \\
\hline Month 2 & $44.6 \pm 15.1^{2}$ & $44.7 \pm 12.3^{1}$ \\
\hline Month 6 & $3.94 \pm 0.48$ & $4.30 \pm 0.95$ \\
\hline
\end{tabular}

* ANCOVA adjusted for subject age and sex; ' Change from baseline $(p<$ $0.005) ;{ }^{2}$ Change from baseline $(p<0.04) ;{ }^{3}$ Between-group mean difference $(p \leq 0.00 \mathrm{I}) ;{ }^{4}$ Between-group difference $(p=0.012)$ 
significant increases over baseline during all four supplementation months. The micronutrient group also had significantly higher mean zinc intakes compared to the placebo group during study months 1-4. However, significant between-group differences in mean vitamin A intake were identified only during months 2-3. A review of the 24-hour dietary data suggested that large intra-subject variations in the consumption of vitamin A-rich food sources were responsible (e.g., beef, liver, eggs). The two groups had comparable baseline and monthly mean intakes of energy, protein (Table II) and vitamin $\mathrm{D}$, cholesterol and other major nutrients (data not shown).

The micronutrient but not the placebo group showed a significant rise in mean plasma zinc levels at study month 2 compared to baseline (Table II). At month 2 , the mean plasma zinc of the micronutrient group also was significantly higher compared to the placebo group. Although mean serum retinol levels steadily increased over baseline value as the study progressed, no significant between-group differences were recorded. This was most likely due to the previously noted subject intra-variation in vitamin A foods.

Figure 1 displays the proportion of subjects in the two study groups with a positive sputum smear from baseline through study month 6 . The proportion of positive smears in both groups decreased over time until by the fifth month, none remained positive. The rate of decline was more pronounced in the micronutrient group but these differences only became statistically significant at month 3.

As Figure 2 shows, both subject groups exhibited a decreased Th1 immune response (i.e., low mRNAIFN- $\gamma$ ) and an elevated $\mathrm{T}$ regulatory (Treg) cytokine (mRNA IL-10) profile at baseline characteristic of untreated pulmonary TB.,12 Increases in IL-10 and suppression of Th1 response have an adverse effect on IFN- $\gamma$ availability. In addition, low TNF- $\alpha$ levels such as those seen at baseline may result from inadequate macrophage response. Progression of untreated Mycobacterium infection results in impairments in both innate and adaptive immune response leading to bacterial replication and disease chronicity (Figure 2).

\section{Discussion}

Similar to other reports, ${ }^{7}$ with chemotherapy, subject cytokine profiles began to shift more towards a Th1 immune response as indicated by increasing mRNA IFN- $\gamma$. The increasing mRNA TNF- $\alpha$ levels were also notable. The status of those two cytokines correlated with decreasing Treg cells activity (i.e., lower mRNA IL-10) in the present study. Although the between-group differences did not achieve statistical significance in this small pilot study, nonetheless, the observed trends in cytokine activity suggest that adjunctive micronutrient therapy acted to enhance bacterial elimination in the supplemented group (Figure 1).

The elevated IFN- $\gamma$ and TNF- $\alpha$ mRNA levels identified for the micronutrient group at study month 2 is consistent with the observed acceleration in their sputum smear conversion rate signaling increased bacterial clearance. Although the TNF- $\alpha$ mRNA of the placebo group also increased over time, it did so more slowly, consistent with the longer time required for conversion to a negative smear. The post hoc analyses identified a significant positive correlation between plasma zinc and TNF- $\alpha$ mRNA levels at month $2(r=0.47, p=0.03)$. The available evidence suggests that standard antibiotic TB treatment is associated with the upregulation of Th1 response, bacterial clearance and clinical improvement. ${ }^{13}$ In our study, adjunctive zinc supplementation appeared to accelerate this process. The effect of vitamin A supplementation was less evident.

The results of this initial study suggest that adjunctive micronutrient supplementation accelerated the beneficial therapeutic effect of TB chemotherapy by improving zinc status and Th1 immune response. Larger clinical studies are required to verify these initial results. If confirmed, adjunctive therapy could be used to shorten the amount of time that TB patients are contagious, thereby reducing the potential for disease spread and allowing them a faster return to work and society.

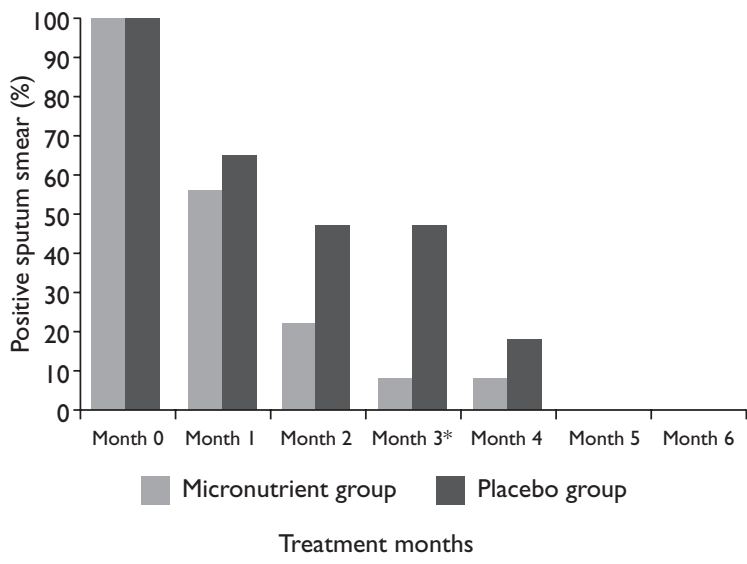

"Fisher's exact test, 2-tailed $p=0.033$ (Month 3)

Figure I. Comparison of SPUTUM SMEar CONVERSion IN THE MICRONUTRIENT $(\mathrm{N}=\mathrm{I7})$ AND PLACEBO GROUPS $(\mathrm{N}=16)$ AT BASELINE (MONTH 0 ), SUPPLEMENTATION PERIOD (MONTHS I-4), AND POST-SUPPLEMENTATION PERIOD (MONTHS 5-6). Ciudad Juárez, Chinuahua, Mexico, 2005-2006 
(2a) IFN- $\gamma$ mRNA levels*

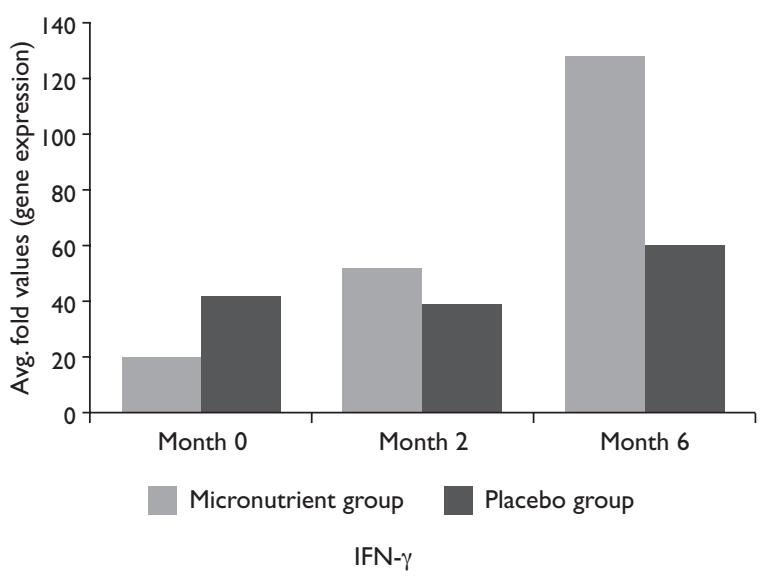

(2b) TNF- $\alpha$ mRNA levels*

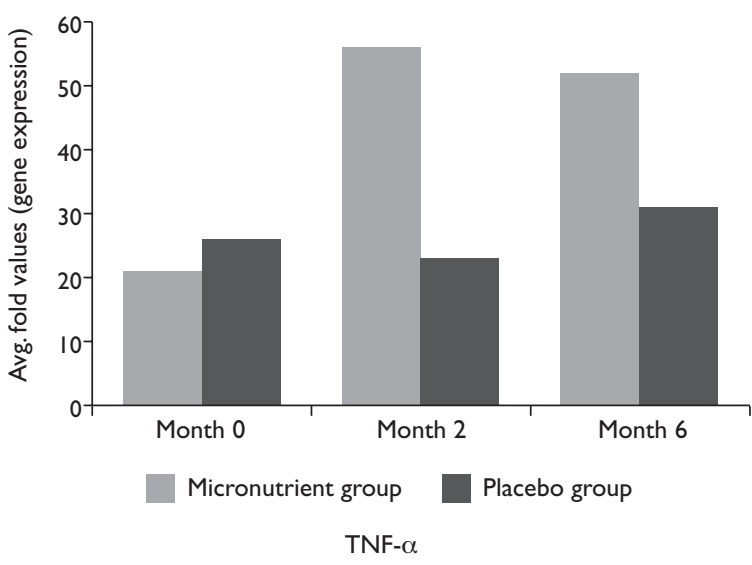

(2c) IL-10 mRNA levels*

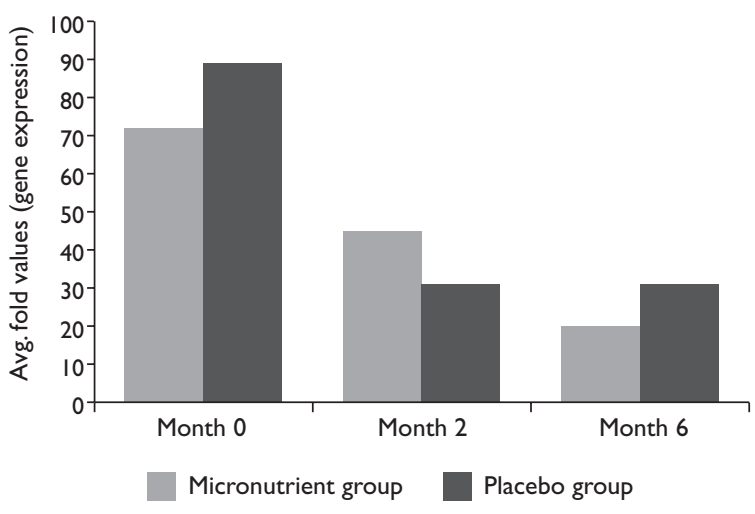

IL-10

$*_{p}>0.05$

Figure 2. Comparison of Cytokine (IFN- $\gamma$, TNF- $\alpha$,IL-I0) MRNA EXPRESSION LEVELS IN THE MICRONUTRIENT ( $N=17$ ) AND PLACEBO $(\mathrm{N}=16)$ GROUPS AT BASELINE (MONTH 0 ) AND SUPPLEMENTATION MONTH 2 AND POST-SUPPLEMENTATION MONTH 6. Ciudad Juárez, Chinuahua, Mexico, 2005-2006

\section{Acknowledgements}

This project was supported by the Center for Border Health Research, an initiative of the Paso del Norte Health Foundation and the UTEP-UTSPH Hispanic Health Disparities Research Center. The authors also gratefully acknowledge the excellent technical assistance of Dr. Enrique Bravo, Dr. Carlos Porras, Dr. Julia Alvarez, Dr. Guadalupe Romero, Dr. Juana Trejo, Dr. Adriana Dominquez, Dr. Alberto Martinez, Febe Huitron, Genoveva Cordero, Marcela Gonzalez and Alma Lorena Rodriguez.

\section{References}

I. Karyadi E, Schultink W, Nelwan RHH, Gross R,Amin Z, Dolmans WMV, et al. Poor Micronutrient Status of Active Pulmonary Tuberculosis Patients in Indonesia. J Nutr 2002; 130:2953-2958.

2. van Lettow M,West CE, van der Meer JW,Wieringa FT, Semba RD. Low plasma selenium concentrations, high plasma human immunodeficiency virus load and high interleukin- 6 concentrations are risk factors associated with anemia in adults presenting with pulmonary tuberculosis in Zomba district, Malawi. Eur J Clin Nutr 2005; 59(4):526-532.

3. McMurray DN, Bartow RA, Mintzer CL, Hernandez-Frontera E. Micronutrient status and immune function in tuberculosis. Ann NYAcad Sci 1990;587:59-69.

4. Karyadi E,West CE, Schultink W, Nelwan WH, Gross R, Amin Z, et al.A double-blind, placebo-controlled study of vitamin $A$ and zinc supplementation in persons with tuberculosis in Indonesia: effects on clinical response and nutritional status. Am J Clin Nutr 2002;75(4):720-727. 5. Flynn J,Chan J. Immunology of tuberculosis. Ann Rev Immunol 2001;19:93-129.

6. Boussiotis VA, Tsai EY,Yumis EJ, Thim S, Delgado JC, Dascher CC, et al. IL-10 producing $T$ cells suppress immune response in anergic tuberculosis patients.J Clin Invest 2000; 105:1317-1325.

7. Geffner L,Yokobori N, Basile J, Schierloh P, Balboa L, Romero M, et al. Patients with multidrug tuberculosis display impaired ThI responses and enhanced regulatory T-cell levels in response to an outbreak of multidrugresistant Mycobacterium tuberculosis $\mathrm{M}$ and Ra strains. Infection and Immunity 2009;77:5025-5034.

8. Karyadi E, Dolmans WM, West CE,Van Crevel R, Nelwan RH,Amin Z, et al. Cytokines related to nutritional status in patients with untreated pulmonary tuberculosis in Indonesia. Asia Pac J Clin Nutr 2007; 16(2):218-226.

9. Range N,Andersen AB, Magnussen P, Mugomela A, Friis H.The effect of micronutrient supplementation on treatment outcome in patients with pulmonary tuberculosis: a randomized controlled trial in Mwanza, Tanzania. Trop Med Int Health 2005; 10(9):826-32.

10. Chandra RK. Nutrient supplementation as adjunct therapy in pulmonary tuberculosis. Int JVitam Nutr Res 2004;74(2): I44-I46. I I. Mathur M. Role of vitamin A supplementation in the treatment of tuberculosis. Nat Med J India 2007;20: 16-21.

12. Hernandez-Pando R, Orosco H,Aguilar D. Factors that deregulate the protective immune response in tuberculosis. Arch Immunol Ther Exp 2009;57:355-367.

13. Hirsch C, Toossi Z, Othieno C, Johnson J, Schwander S, Robertson S et al. Depressed T-Cell Interferon-g Responses in Pulmonary Tuberculosis: Analysis of Underlying Mechanisms and Modulation with Therapy.J Infect Dis 1999;180:2069-2073. 